\title{
QUESTÁO DA QUALIDADE BACTERIOLÓGICA DA ÁGUA DOS RIOS MACACU, CACERIBU, GUAPI-AÇU E GUAPI-MACACU, RJ, BRASIL
}

\author{
Myriam Bandeira Vianna ${ }^{1}$ \\ Julio Cesar Wasserman ${ }^{2}$ \\ Otílio Machado Bastos ${ }^{3}$ \\ Renato Gomes Sobral Barcellos ${ }^{4}$ \\ Alynne Silva Barbosa
}

\begin{abstract}
Resumo: A importância da manutenção da qualidade da água dos corpos d'água que abastecem as cidades se deve não somente ao cuidado com a saúde dos que a consomem, mas também aos elevados custos com os tratamentos. O presente trabalho teve como objetivo fazer o diagnóstico bacteriológico da água dos rios Macacu, Caceribu, Guapi-Açu e Guapi-Macacu. Os mananciais estudados estáo situados na área de influência do COMPERJ, fazendo parte da bacia do GuapiMacacu, responsável pelo abastecimento dos municípios de Niterói, São Gonçalo, Itaboraí e Ilha de Paquetá, no Estado do Rio de Janeiro, Brasil. Durante um período de nove meses, foram realizadas análises bacteriológicas mensais para bactérias coliformes totais e termotolerantes para a avaliação da qualidade da água. As análises serviram de base para as medidas propostas para melhorar o controle das bactérias contaminantes, como parte do sistema de gestão da qualidade da água para consumo humano da regiáo em foco. Foram coletadas 81 amostras de água de 9 pontos diferentes. As análises bacteriológicas foram realizadas pelo método do Número Mais Provável (NMP) utilizando a técnica dos tubos múltiplos. Os resultados das análises indicaram NMP elevados de coliformes totais e termotolerantes para todos os pontos, acima dos previstos pelas normas ambientais de potabilidade e balneabilidade para todos os pontos pesquisados. Observou-se que visando ao fornecimento de água de boa qualidade para consumo humano é necessário que as empresas de água e as agências ambientais desenvolvam sistemas de monitoramento para o controle da qualidade da água e açóes para melhorar os índices de contaminação da água bruta.
\end{abstract}

Palavras- Chave: Qualidade de água, Recursos hídricos, Avaliação sanitária, Coliformes.

Abstract: The maintenance of the water quality in the bodies that supply cities does not only concern the care with health of those who consume, but also the high costs of treatments. This study aimed to carry out a diagnosis of the bacteriological contamination of the waters from the Macacu, Caceribu ,Guapi-Açu and Guapi-Macacu rivers. These rivers are located in the area of influence of Petrochemical Complex of Rio de Janeiro - COMPERJ (Itaboraí, Rio de Janeiro) part of the basin of the Guapi-Macacu is responsible for supplying water to the cities of Niterói, São Gonçalo, Itaboraí and Paquetá Island. Microbiological tests were performed on a monthly basis for nine months for total and thermotolerant coliform bacteria in nine sampling sites. The analysis provided the basis for the proposed measurements to improve the control of possible bacteriological contaminants, as part

1 Rede UFF de Meio Ambiente e Desenvolvimento Sustentável - REMADS-UFF. Rua Passo da Pátria 156, Bloco E, sala 453, CEP 24210-240, Niterói, RJ, Brasil. E-mail: mbviann@gmail.com

2 REMADS-UFF. E-mail: geowass@vm.uff.br

3 Departamento de Microbiologia e Parasitologia, UFF. Rua Prof. Ernani Pires de Melo, 101, CEP: 24210-130, Niterói, RJ, Brasil. E-mail: otiliobastos@gmail.com

4 Instituto Federal Fluminense de Educação, Ciência e Tecnologia, Campus Quissamã, Av. Amilcar Pereira da Silva, 727, Piteiras, Quissamã, RJ, CEP: 28735 970. Email: rbarcellos@iff.edu.br

5 Departamento de Microbiologia e Parasitologia, UFF. E-mail: alynnedsb@gmail.com 
of the management system of the water quality in the focused region. Microbiological tests were performed by using the Most Probable Number (MPN) technique with the multiple tubes method. The bacteriological analysis showed high MPN for total coliforms and thermotolerant in all sampling sites, always above the environmental standards set for drinking and balneability. The results showed that the water quality is a crucial issue that has to be dealt with by water companies and environmental agencies that are suggested to follow closely the sanitary parameters and proceed to the management of the resources, in order to provide good water to the consumers.

Key words: Water quality, Water resources, Sanitary evaluation, Coliform. 


\section{INTRODUÇÃO}

O homem paga hoje, um alto preço em decorrência do desmatamento das margens dos rios, do crescimento demográfico, da rápida urbanização e dos lançamentos de esgotos domésticos e efluentes sem tratamento nos mananciais. Tais atos respondem pela contaminação das águas, tornando mais grave a relação água-doença-saúde (Machado e Klein, 2003).

A água para o consumo do homem e animais precisa ser livre de agentes contaminantes, sendo os agentes biológicos um dos fatores mais importantes de sua contaminaçáo (Loureiro et al., 2007). Muitas são as doenças de veiculação hídrica que podem tornar-se um importante elemento de risco à saúde pública. Estas doenças são transmitidas através da rota oro-fecal, quando microrganismos patogênicos são excretados através das fezes do homem e dos animais, ocorrendo principalmente em locais em condiçôes sanitárias deficitárias (Almeida et al., 2004, Loureiro et al., 2007).

Dentre os patógenos costumeira-mente isolados na água estão as bactérias da família Enterobacteriaceae, constituída por bacilos gram-negativos com muitas propriedades em comum. A família das Enterobacteriaceae é formada por 32 gêneros e 130 espécies de variada importância médica, sendo que 20 dessas espécies são causadoras de $95 \%$ das infecçóes correntes. Microrganismos ubíquos, essas bactérias fazem parte da microbiota intestinal do homem e de grande parte dos animais, sendo encontradas na água, no solo e em vegetaçóes no mundo todo (Hoadley et al., 1977). Estas enterobacterias acometem principalmente idosos, imunodeprimidos, portadores de doenças graves e crianças, especialmente aquelas menores de dois anos de idade. Os pacientes, juntamente com os indivíduos assintomáticos, possuem significativa importância na epidemiologia das gastroenterites infecciosas (Obi et al., 2003). Agentes de contaminaçáo, as enterobacterias respondem diretamente pelo aumento do número de infectados, uma vez que a deposição dos agentes patogênicos no ambiente propicia a contaminação da água, do solo, da vegetação e dos alimentos (Silva e Ferreira, 1997). Dentre as enterobactérias, os bacilos do grupo dos coliformes têm sido utilizados como referência de contaminação, permitindo aferir a presença fecal na água há mais de 124 anos, desde a sua descoberta por Escherich em 1885 (Bettega et al., 2006, Rompré et al., 2002, Silva e Ferreira, 1997).

Esses organismos são classificados em grupo dos coliformes totais e dos coliformes termotolerantes. Os coliformes totais são constituídos por bactérias em forma de bastonetes Gram-negativos, aeróbios ou anaeróbios facultativos, não produtores de esporos, capazes de fermentar a lactose com produção de gás à temperatura de $35^{\circ} \mathrm{C}$ em um período de 24 a 48 horas (APHA, 1995, Forsythe, 2002, Loureiro et al., 2007).

O outro grupo é o dos coliformes termotolerantes, dentre os quais a Escherichia é o gênero mais conhecido, porque tem o seu habitat no trato gastrintestinal. Abundante em fezes humanas e de outros animais foi encontrada em esgotos, efluentes, águas naturais e solos que tenham recebido contaminação fecal recente (Silva e Ferreira, 1997).

A Escherichia Coli foi escolhida dentre as bactérias termotolerantes, como o organismo indicador de contaminação fecal e mantém o "status" de melhor indicador de poluição fecal, até os dias de hoje (Bettega et al., 2006, Rompré et al., 2002, Silva e Ferreira, 1997). Escherichia coli é o componente taxonomicamente mais bem definido da família Enterobacteriaceae, possuidora de características bioquímicas que facilitam a distinção dos coliformes termotolerantes. Possui a propriedade de fermentar a lactose e o manitol, com produção de gás e a capacidade de produzir a partir do triptofano o indol, além de produzir as enzimas $ß$-glicuronidase e $ß$-galactosidade. Cresce normalmente à temperatura de $44,5^{\circ} \mathrm{C}$, no entanto algumas cepas podem crescer a $37^{\circ} \mathrm{C}$ (Loureiro et al., 2007, Silva e Ferreira, 1997).

O gênero Escherichia apresenta cinco espécies, das quais a $E$. coli é a que apresenta maior relevância clínica, sendo também a mais comumente encontrada. Pode provocar no hospedeiro, em virtude da sua diversidade antigênica uma multiplicidade de doenças, inclusive sepse, infecçóes das vias urinárias, meningite e gastrenterite (Müller et al., 2007).

É proposta deste trabalho, analisar a qualidade bacteriológica das águas dos rios Macacu, Guapi-Açu, Guapi-Macacu e Caceribu, considerando que a água é um recurso finito, cuja qualidade vem sendo comprometida pelo aumento crescente da poluição e pelas políticas públicas de- 
ficitárias de gestão dos recursos hídricos. Embora alguns projetos significativos já venham sendo desenvolvidos na região e já exista uma previsão de investimentos, através do Projeto de Recuperação Ambiental da Bacia do Rio Macacu, as ações são ainda muito tímidas para garantir a qualidade da água para uso humano.

A larga utilização das águas dos rios estudados náo se restringe ao abastecimento e uso pelas populaçóes da região, mas também estão na região de influência direta do pólo petroquímico do Rio de Janeiro (COMPERJ), gerando um conflito de uso que contribuirá não somente para agravar a escassez do recurso, mas também deve trazer problemas à saúde pública, daí a necessidade do acompanhamento sistemático e periódico das alteraçôes da qualidade da água.

\section{METODOLOGIA}

\subsection{DESCRIÇÃO DA ÁREA DE ESTUDOS}

No Rio de Janeiro, a Região Hidrográfica da Baía de Guanabara está dividida em 39 sub-regióes, divisão que é composta por 12 bacias de grande relevância que contribuem diretamente para a baía (Ecologus e Agrar, 2003). Dentre estas bacias destacam-se as dos rios Macacu, Guapi-Açu, Caceribu e Guapi-Macacu, as quais foram consideravelmente modificadas pelo homem (Figura 1). O Rio Guapi-Macacu teve o seu nome originado a partir da construção do canal de Imunana que reduziu a incidência das freqüentes inundações conseqüentes da confluência dos rios Macacu e Guapi-Açu (Dantas et al., 2008). Ao ser desviado do seu curso natural, o rio Macacu passou a desaguar no rio Guapimirim (Dantas et al., 2008).

O rio Caceribu também teve a sua bacia isolada e deixou de ser afluente pela margem esquerda do rio Macacu, passando a ocupar o antigo baixo leito do rio Macacu, com a sua foz na APA de Guapimirim (maior área de mangue remanescente na baía de Guanabara), desaguando a nordeste, no recôncavo da baía de Guanabara (Costa, 1999).

A bacia hidrográfica do rio Guapi-Macacu, é constituída pelos rios Macacu, Guapiaçu e Guapimirim, totalizando uma área de $1640 \mathrm{~km}^{2}$ (Dantas et al., 2008, Instituto Brasileiro de Geografia e Estatís- tica, 2009), enquanto a bacia de drenagem do Caceribu tem $860 \mathrm{~km}^{2}$, sendo estes dois rios os principais contribuintes da Baía de Guanabara.

O Clima na região é quente e chuvoso, tipicamente tropical, com médias de chuvas anuais entre 1200 e $1600 \mathrm{~mm}$ (Amador, 1997), sendo do tipo AW, de acordo com a classificação de Köppen (Köppen, 1948).

Os meses do verão (dezembro, janeiro e fevereiro) são bastante úmidos com pluviosidade de até $350 \mathrm{~mm}$. Já no período seco de inverno este padrão se reverte, quando as pluviosidades não ultrapassam $90 \mathrm{~mm}$ por mês. Observa-se ainda que a pluviosidade se intensifica em direção à Serra do Mar, onde os valores são bastante elevados. Como já dito anteriormente, a chuva abastece abundantemente os solos da regiáo, contudo a reduzida dimensão das bacias de drenagem não permite a criação de um estoque de água, como é o caso do Rio Paraíba do Sul.

\subsection{AMOSTRAGENS}

Foram coletadas oitenta e uma amostras de água distribuídas em nove estaçóes (Figura 1), num período de nove meses, de 23 de março a 17 de novembro de 2009, onde foram realizados testes de colimetria. Os pontos de coleta foram distribuídos ao longo dos rios Macacu, Guapi-Macacu, Guapiaçu e Caceribu que fazem parte do sistema de abastecimento das cidades de Niterói, São Gonçalo, Itaboraí, Cachoeiras de Macacu e Ilha de Paquetá, a montante e a jusante do futuro Complexo Petroquímico do Rio de Janeiro (COMPERJ).

A escolha das Estaçóes de Coleta teve por base, a avaliação da qualidade das águas dos rios que abastecem as cinco localidades e os possíveis impactos causados pelas atividades desenvolvidas ao longo dos seus cursos. As atividades pastoris e a proximidade com o COMPERJ são fatores que podem estar afetando os seus usos preponderantes de potabilidade e balneabilidade (Tabela 1). Na Tabela 1 foram também incluídas as coordenadas geográficas planas de cada estação.

Conforme observado nos trabalhos de campo, a maioria dos pontos (RM1, RM2, RGA3, RM4, RC1 e RC2) está localizada em áreas muito próximas de pastos de gado de corte, condição que favorece, no período das chuvas, o arrasto de matéria orgânica para a água. Sendo que no caso do rio Caceribu, um fato que chama a atenção é 


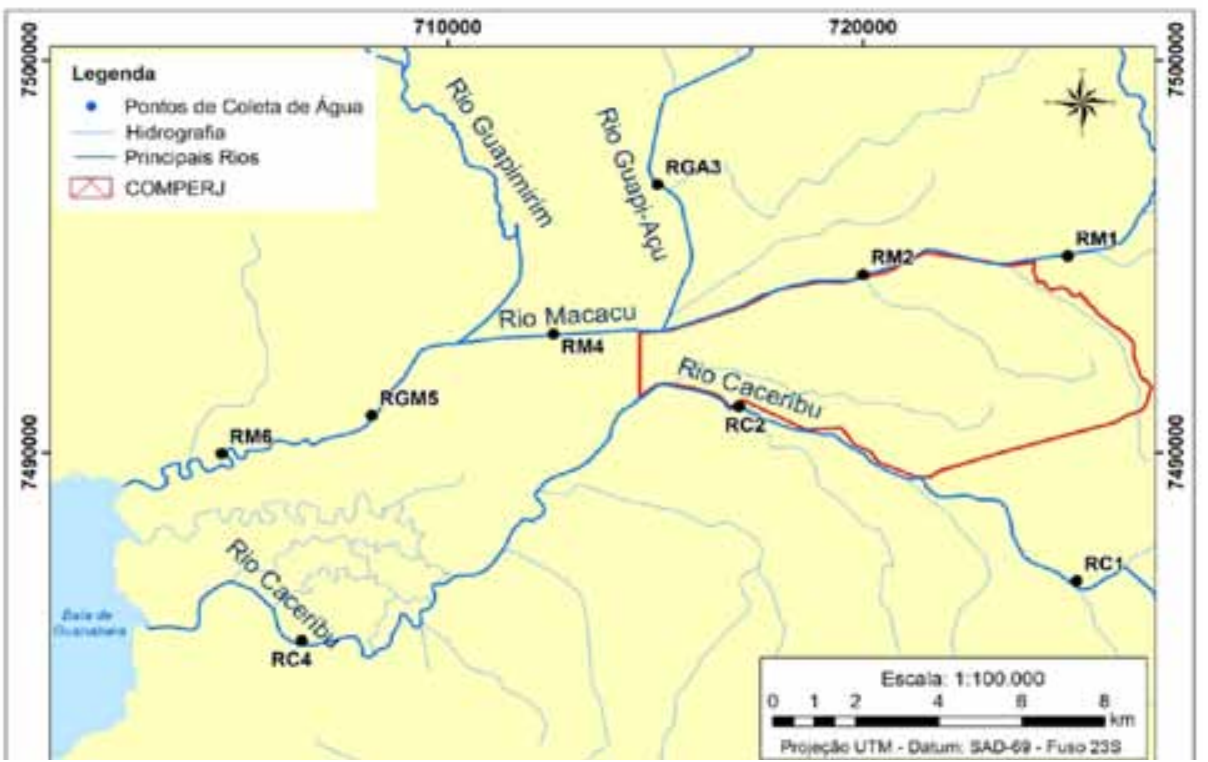

Figura 1: Posição das estaçóes de amostragem nos rios Macacu, Guapi-Açu e Guapi-Macacu em relação à área do Complexo Petroquímico do Rio de Janeiro (COMPERJ).

\begin{tabular}{|c|c|c|c|}
\hline Estaçóes & Localização & $\mathbf{N}$ & $\mathbf{E}$ \\
\hline RM1 & $\begin{array}{l}\text { A montante do Rio Macacu- } \\
\text { limite noroeste do COMPERJ }\end{array}$ & 725050 & 7495006 \\
\hline RM2 & $\begin{array}{l}\text { No rio Macacu, próximo } \\
\text { à drenagem do terreno do } \\
\text { COMPERJ }\end{array}$ & 725050 & 7486699 \\
\hline RGA3 & $\begin{array}{l}\text { No Rio Guapiaçu, contribui } \\
\text { significativamente com } \\
\text { suas águas para a Estação } \\
\text { de Tratamento de Águas de } \\
\text { Imunana-Laranjal. }\end{array}$ & 716904 & 7491155 \\
\hline RM4 & Na Represa da CEDAE. & 716904 & 7491155 \\
\hline RGM5 & $\begin{array}{c}\text { A jusante da Represa da } \\
\text { CEDAE, próximo à ponte da } \\
\text { BR-493 }\end{array}$ & 708161 & 7490868 \\
\hline RM6 & $\begin{array}{l}\text { Estação situada no manguezal } \\
\text { em Guapimirim, próximo à foz } \\
\text { na baía de Guanabara. }\end{array}$ & 710194 & 7486782 \\
\hline $\mathrm{RC} 1$ & $\begin{array}{l}\text { A montante do Rio Caceribu, } \\
\text { em relação ao COMPERJ - } \\
\text { ponte da rodovia RJ } 116 \text { sobre } \\
\text { o Caceribu. }\end{array}$ & 715827 & 7494711 \\
\hline $\mathrm{RC} 2$ & $\begin{array}{c}\text { Estação mais próxima } \\
\text { do COMPERJ, local de } \\
\text { possibilidade de maior impacto } \\
\text { causado pelo empreendimento. }\end{array}$ & 704366 & 7490118 \\
\hline RC4 & $\begin{array}{l}\text { Estação situada no manguezal } \\
\text { em Guapimirim próximo à foz } \\
\text { na Baía de Guanabara. }\end{array}$ & 719926 & 7494509 \\
\hline
\end{tabular}

Tabela 1: Localização das estaçôes de coleta de água nas bacias dos rios Macacu, Guapiaçu, Guapi-Macacu, Caceribu, todos localizados na Baixada Fluminense, RJ, 2009, e suas coordenadas através do GPS. 
a proximidade do aterro sanitário de Tanguá, que recebe o lixo do município após a sua passagem pela usina de compostagem. O aterro está próximo a uma vala (provavelmente contaminada com chorume), que deságua em uma lagoa de estabilização que possui ligação direta com o rio Caceribu. $\mathrm{O}$ aterro encontra-se nas proximidades da elevatória da CEDAE (Ecologus e Agrar, 2003).

De acordo com a classificaçáo estabelecida na Resolução CONAMA 357/2005 (BRASIL, 2005), as águas das estaçóes de coletas situadas no rio Macacu RM1, RM2, RM4, mais a estação situada no rio Guapiaçu RGA3, e ainda as estaçóes RC1 e RC2, ambas no rio Caceribu, são classificadas como pertencentes à categoria de Água Doce, Classe 3. Essas águas, segundo a legislação, podem ser destinadas ao abastecimento para consumo humano, após tratamento convencional ou avançado; à irrigação de culturas (arbóreas cerealíferas e forrageiras); à pesca amadora; recreação de contato secundário e à dessedentaçáo de animais. As águas das estações de coleta RGM5, RM6 localizados no rio Macacu e RC4 localizados no rio Caceribu, por sua vez, foram colocadas na Classe 2, relativa às águas salobras. As águas salobras da classe 2 são destinadas à pesca amadora e à recreação de contato secundário.

\subsection{PROCEDIMENTOS ANALÍTICOS BACTERIOLÓGICOS}

Para as coletas das amostras dedicadas às análises microbiológicas (Colimetria) foram utilizados frascos, devidamente esterilizados e mergulhados a uma profundidade de $20 \mathrm{~cm}$. Os frascos de vidro têm a capacidade de $500 \mathrm{~mL}$, deste modo há espaço disponível para agitação da água antes das análises (Soares e Maia, 1999).

Os frascos foram previamente lavados com detergente e enxaguados, o último enxágüe foi realizado com água destilada, sendo em seguida esterilizados em autoclave por um período de 15 minutos, a uma temperatura de $121^{\circ} \mathrm{C}$ (APHA, 1995). O teste controle foi feito com amostra de água esterilizada e autoclavada a $121^{\circ} \mathrm{C}$ por 15 minutos, posteriormente analisado o NMP de coliformes totais e termotolerantes pela técnica dos tubos múltiplos. As amostras coletadas foram devidamente identifi-cadas, de acordo com o local de coleta, seguindo acondicionadas em bolsa térmica contendo gelo, para o laboratório onde foram realizadas as análises. $\mathrm{O}$ intervalo entre a coleta e as análises náo ultrapassou o limite de seis horas para os exames bacteriológicos na pesquisa do NMP (Número Mais Provável) de Coliformes Totais e Coliformes Fecais. Estas análises foram realizadas segundo a metodologia dos tubos múltiplos, conforme descrito em APHA (1995).

\section{RESULTADOS}

As figuras 2 a 5 mostram que os valores bacteriológicos encontrados nas águas dos rios Macacu e Caceribu, apresentaram superioridade numérica para o Macacu em relação ao Caceribu. As variaçóes ocorridas no NMP de coliformes totais e termotolerantes, aparentemente não sofreram influência sazonal, ocorrendo valores altos e baixos, em qualquer dos períodos, secos ou chuvosos, com vazão baixa ou alta. Esses resultados diferem daqueles apontados na literatura, em que na estação chuvosa o escoamento superficial é o fator que mais contribui para a modificação da qualidade microbiológica dos corpos d'água, em decorrência do aumento da quantidade de sedimentos e excretas de origem humana e animal, que são carreados para o leito do rio (Amaral et al., 2003). Nos pontos em que o NMP foi $\geq 1600$ pode ter ocorrido uma diminuição dos coliformes que estavam acima de 1600, mas que não foi detectada por limitação do próprio método, mais adequado a valores baixo, utilizado para aferir a potabilidade.

Os números mais prováveis (NMP) de coliformes totais e termotolerantes apresentados a seguir, são considerados para cada $100 \mathrm{~mL}$ da amostra.

Uma das razóes que pode levar a crer, que a influência sazonal é pouco significativa, se deve aos valores de coliformes totais e termotolerantes que ocorreram no ponto RGM5. Este ponto por ser a porção retificada do rio Guapi-Macacu, sujeito às condiçôes hidrodinâmicas com oscilaçôes maregráficas que possibilitam a ocorrência de variaçôes de volume, exclusivamente por conta desta forçante, apresenta vazão muito maior ao longo dos meses, em relação aos outros pontos. Apesar disso, o NMP de coliformes apresentou valores altos e baixos, independentemente do volume da vazão e da época estacional, se seca ou chuvosa, náo havendo diluiçáo por conta do aumento da vazão. 


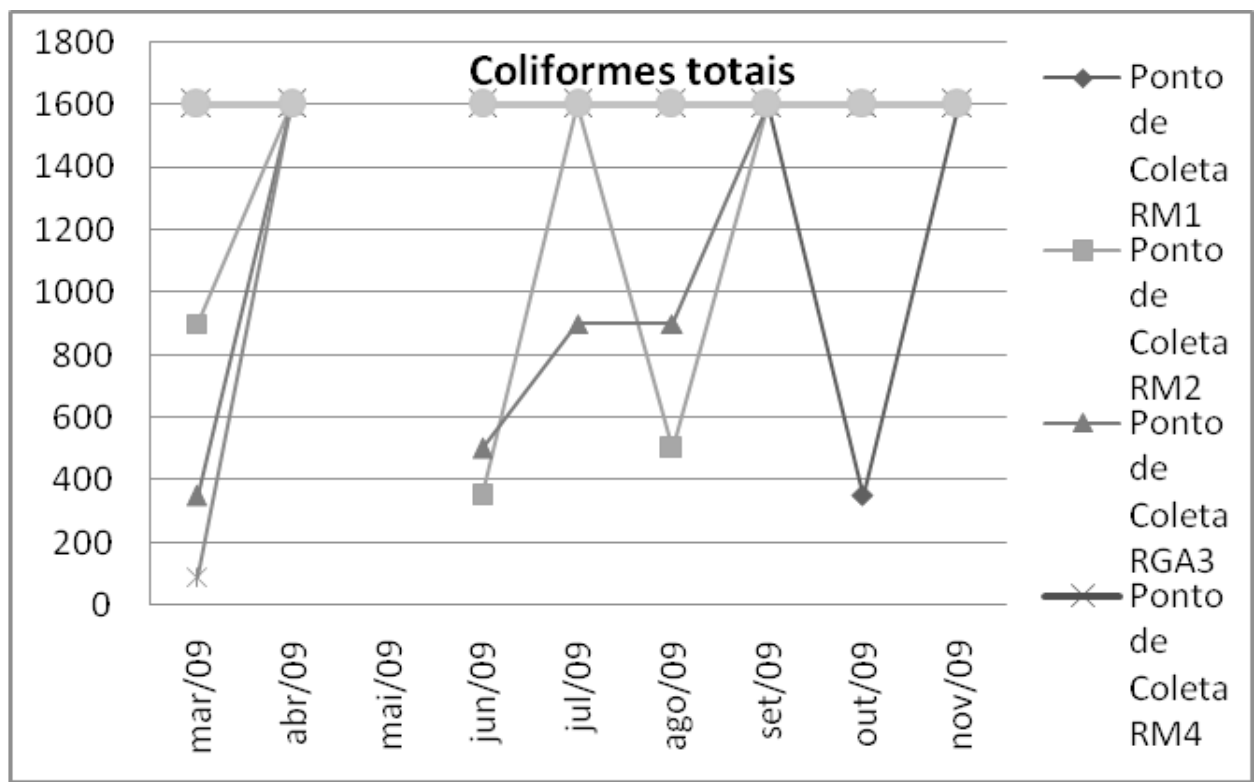

Figura 2: NMP de coliformes totais nos pontos de coleta do rio Macacu

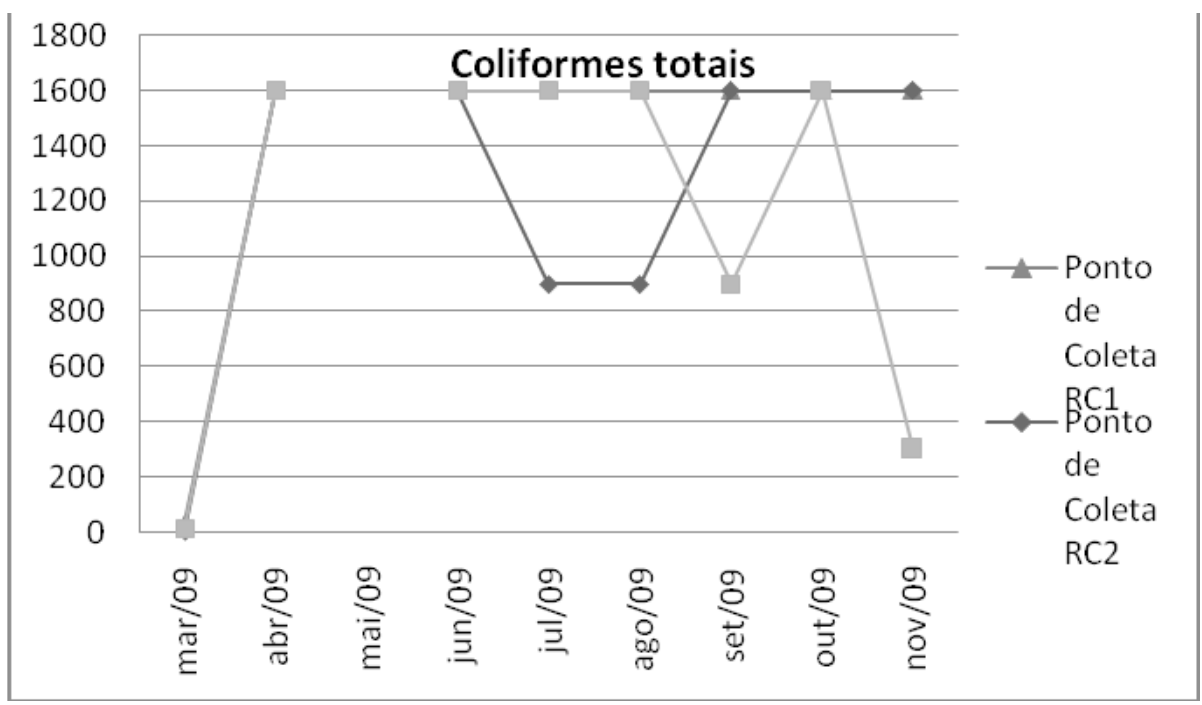

Figura 3: NMP de coliformes termotolerantes nos pontos de coleta do rio Macacu, Guapi-Açu, Guapi-Macacu

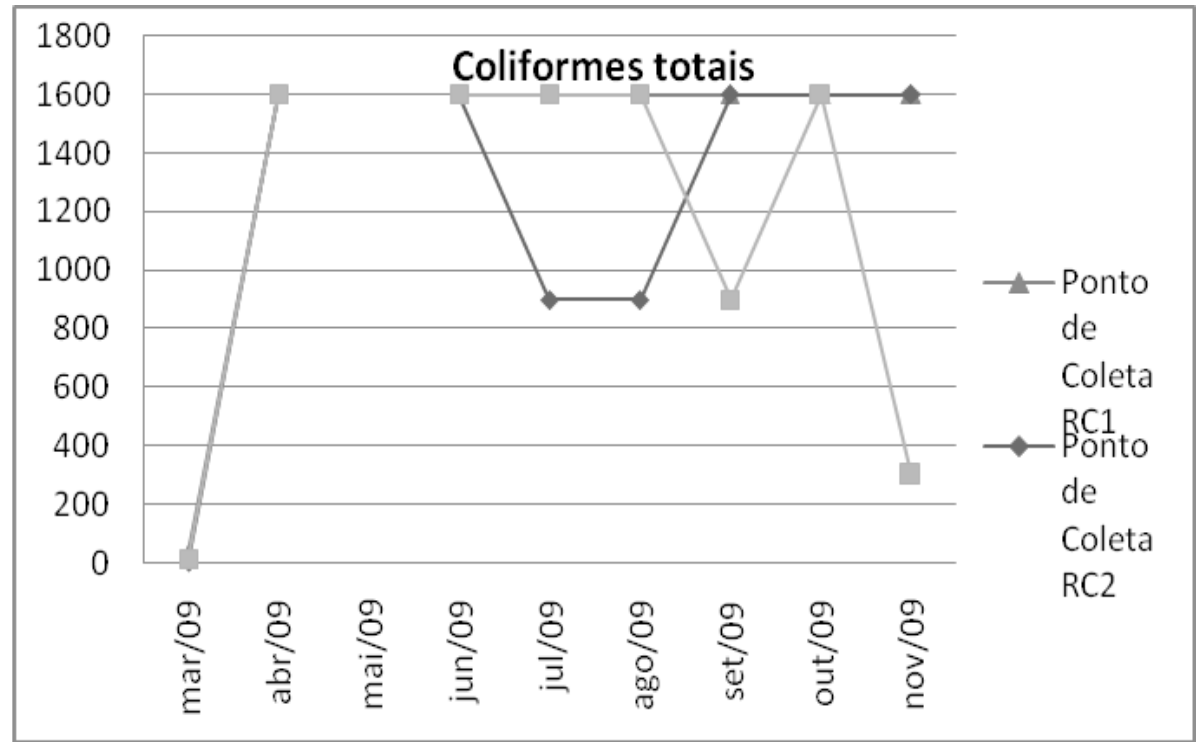

Figura 4: NMP de coliformes totais nos pontos de coleta do rio Caceribú 


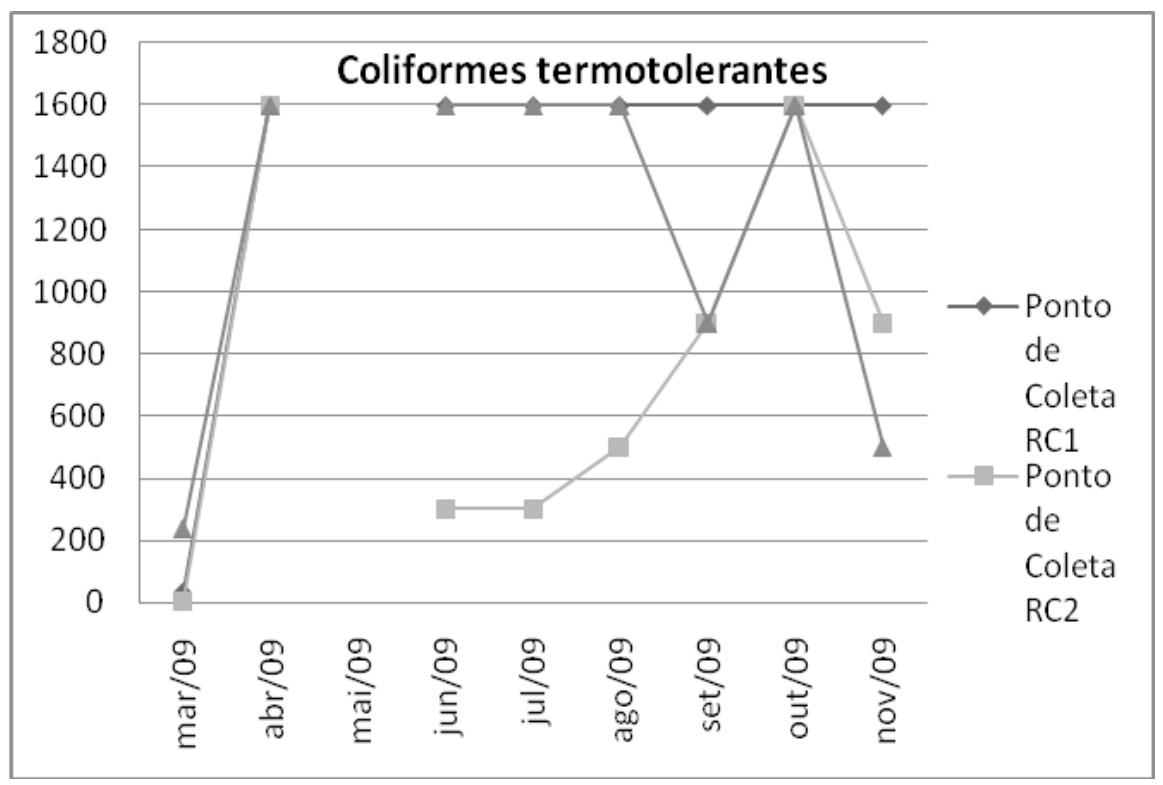

Figura 5: NMP de coliformes termotolerantes nos pontos de coleta do rio Caceribú

Os rios Macacu e Caceribu apresentaram NMP de coliformes totais e termotolerantes, muito acima dos valores estabelecidos na Portaria do Ministério da Saúde 518/04, que determina os padrôes de potabilidade e da Resoluçáo CONAMA 274/2000 (Brasil, 2000) que define a balneabilidade, ambas de acordo com os usos preponderantes desses rios. No caso da potabilidade, a norma prevê ausência de coliformes totais e de termotolerantes em $100 \mathrm{~mL}$ e, em se tratando da balneabilidade, no caso o uso visando à recreaçáo de contato primário é considerado satisfatório, quando os valores de coliformes termotolerantes forem inferiores a 1000 por $100 \mathrm{~mL}$. Para os demais usos o NMP não deveria ter excedido o limite de 200 coliformes por $100 \mathrm{~mL}$.

Os rios objetos desta pesquisa apresentaram NMP de coliformes totais e termotolerantes muito altos, demonstrando a contaminaçáo por coliformes e a grande variabilidade dos valores ao longo dos meses conforme demonstram as figuras no 2 a 5 .

Os resultados são compatíveis com a pressão que esses rios vêm sofrendo ao longo dos seus cursos, sendo alvo constante de fontes poluentes pontuais e difusas.

Embora a identificação dessas fontes, não seja a proposta deste trabalho, observamos próximo às margens do rio Macacu, o cemitério do município de Cachoeiras de Macacu, e no ponto RM2 uma tubulaçáo de esgoto. E mais, de acordo com o relatório da Ecologus e Agrar (2003), algumas empresas que desenvolvem atividades po- tencialmente poluidoras, estáo situadas na área da bacia do Guapi-Macacu, a CIBRAPEL- Papel e Embalagens, a CCPL - Macacu, a Klabin Fábrica de Papel e Celulose S/A e a fábrica de bebidas Schincariol situada no município de Cachoeiras de Macacu às margens do rio Macacu. Além disto, é necessário frisar que o centro da cidade de Cachoeiras de Macacu situa-se à margem do rio, devendo constituir uma fonte significativa. Deve-se mencionar ainda as inúmeras fazendas situadas à margem do rio, onde existem criaçóes de aves, porcos e mais frequentemente gado, fontes potenciais importantes de coliformes termotolerantes.

No rio Caceribu, foi observado um conjunto residencial construído pela prefeitura de Tanguá, localizado a poucos metros do rio, que provavelmente descarrega os efluentes domésticos diretamente no rio e ainda, o aterro sanitário de Tanguá, que está situado próximo a uma vala que deságua em uma lagoa que por sua vez possui ligaçáo com o rio Caceribu, na Estrada do Minério $s / n^{\circ}$, bairro Bandeirantes I. Na área da bacia do Caceribu também estão localizadas empresas com atividades potencialmente poluidoras, caso $\mathrm{da}$ Companhia Brasileira de Antibióticos (CIBRAN) e da PERMA Indústria de Refrigerantes, também as atividades agrícolas e as residências mais esparsas situadas na região, lançam seus rejeitos no rio.

Observamos a partir de dados de Wasserman et al. (2010) que era de se esperar que índices elevados de poluição microbiológica provocassem uma elevaçáo em alguns parâmetros, caso da $\mathrm{DBO}_{5}$, indicando desse modo atividade 
microbiana intensa, responsável pela depleção do oxigênio dissolvido (Grant e Long, 1989). Isso só foi claramente demonstrado nos pontos RC4, que em todos os meses esteve fora dos limites da legislação e em RM2 que na maior parte dos meses, teve a sua taxa de OD abaixo do previsto pela norma ambiental (Wasserman et al., 2010).

Os valores de fósforo total se mostraram acima do disposto em lei durante todos os meses avaliados, fato que chama a atençáo, pois está ligado ao despejo de poluentes, ou seja, grande quantidade de efluentes ricos em fósforo e nitrogênio que podem contribuir para a intensificação do crescimento microbiano (Payment et al., 1997). Todavia, as águas poluídas podem passar por um processo de autodepuração, e os principais fatores capazes de influenciar a redução do crescimento bacteriano são, de acordo com Kay e McDonald (1980), a temperatura, sedimentação, nutrientes, $\mathrm{pH}$, luz solar, floculação, adsorção, filtração e oxigênio dissolvido. Esta autodepuração está associada principal-mente à produção micro-algal, que deve retirar os poluentes da coluna d'água. Contudo, no estudo dos Rios Macacu e Caceribu realizado por Wasserman et al. (2010) a produção primária foi determinada como muito baixa para este sistema.

\section{CONCLUSÁO.}

Os parâmetros bacteriológicos medidos indicaram NMP de coliformes totais e fecais elevados em todos os pontos, independentemente da sazonalidade, fora daqueles estabelecidos pela legislação pertinente aos seus usos preponderantes. $\mathrm{Na}$ avaliação desses parâmetros, foi observado que os rios Macacu, Guapi-Macacu, Guapi-Açu e Caceribu apresentaram NMP de coliformes totais e termotolerantes muito elevado, caracterizando contaminaçáo fecal que se fez presente da em toda a área de estudos. Deste modo, a qualidade das águas dos rios Macacu, Caceribu, Guapiaçu e Guapi-Macacu devem ser geridas para que seja reduzido o custo de tratamento necessário para que atinja os níveis dispostos na Portaria 518/05 do Ministério da Saúde (ausência de coliformes totais e termotolerantes em $100 \mathrm{~mL}$ ) Para a balneabilidade, deverão ser obedecidos os padróes de qualidade de balneabilidade, previstos na Resolução CONAMA 274 de 2000 (Brasil, 2000).

O número elevado de coliformes totais e termotolerantes provavelmente é conseqüência de lançamento de esgotos in natura que os rios recebem durante sua passagem pelo perímetro urbano e áreas rurais dos municípios participantes das bacias. Além disto, as pastagens e as demais atividades desenvolvidas na região, associadas ao péssimo estado de conservação das matas ciliares, concorrendo para o aumento da poluição microbiológica das águas dos rios estudados.

Finalmente, observamos que existe uma grande variabilidade nos níveis de contaminação por coliformes, podendo ser atribuída às modificaçôes nos parâmetros físico-químicos, na vazão e até nos níveis de insolação e transparência da água (a radiação UV diminui o tempo de sobrevivência das bactérias). Não obstante, as avaliações de colimetria (muitas vezes com frequência semanal) feitas pelas agências ambientais ou pelas empresas de águas não estabelecem relaçóes com nenhum destes parâmetros. Assim, a realização de estudos que correlacionem as variaçốes nos parâmetros da água e a colimetria são necessário a fim de melhorar o entendimento dos processos dinâmicos que afetam os aporte e a sobrevida das bactérias. Nosso grupo de pesquisa desenvolve atualmente um estudo onde são avaliadas as oscilaçóes da colimetria ao longo de estuário, com amostragens a cada três horas. Este trabalho poderá permitir um melhor entendimento da dinâmica de variaçáo da colimetria ao longo de tempos relativamente curtos.

As metodologias atuais para medição da colimetria são baseadas na cultura de colônias, que levam no mínimo 16 horas de incubação. A questão é saber se após neste prazo os valores ainda permanecem ou se a dinâmica é muito mais intensa e os valores oscilam. As implicaçóes em termos de tratamento de água ou de balneabilidade são sérias. Por exemplo, uma placa de liberação da balneabilidade pode ser colocada 16 horas (na melhor das hipóteses) depois da coleta da amostra, em um momento onde a balneabilidade já não estaria mais liberada. Quanto ao tratamento da água, um valor elevado medido 16 horas antes pode levar ao incremento no teor de cloro acrescido à água em um momento onde a contaminação já estaria baixa. Em compensação, 16 horas antes quando a colimetria estava elevada, a quantidade de cloro aplicada foi irremediavelmente baixa.

Considerando que as metodologias para medição da colimetria ainda não evoluíram, é necessário pensar novos procedimentos para a previ- 
são dos níveis de contaminação que dêem respostas em tempo real. $\mathrm{O}$ entendimento dos processos físico-químicos que controlam a coli-metria pode permitir, a partir de mediçóes em tempo real (por exemplo, vazáo, $\mathrm{pH}$, condutividade, oxigênio dissolvido, clorofila a, etc) que se faça previsóes do aumento ou diminuição da contaminação. A partir do entendimento destes processos, seria possível aplicar modelos hidrodinâmicos capazes de simular as taxas de aporte, mortalidade $\left(\mathrm{T}_{90 \%}\right)$ e diluição das bactérias, permitindo uma mais precisa previsão em tempo real dos níveis de contaminação dos recursos hídricos.

\section{AGRADECIMENTOS.}

Este estudo foi financiado com recursos do Projeto "Planejamento Estratégico da Região Hidrográfica dos Rios Guapi-Macacu e Caceribu-Macacu" do Programa Petrobras Ambiental, sob a coordenaçáo geral dos Profs. Antônio Ferreira da Hora, Chou Sin Hwa e Mônica de Aquino Galeano Massera da Hora. JCW agradece ao CNPq por sua bolsa de Produtividade em Pesquisa nível 1 (Proc no. 302197/2009-5).

\section{REFERENCIAS BIBLIOGRÁFICAS.}

ALMEIDA, R. M. A. D., HUSSAR, G. J., PERES, M. R. \& FERRIANI JUNIOR, A. L. 2004. Qualidade microbiológica do córrego "Ribeirão dos Porcos" no município de Espírito Santo do Pinhal - SP. Engenharia Ambiental, 1, 51-56.

AMADOR, E. S. 1997. Baia de Guanabara e Ecossistemas Periféricos: homem e natureza. . Tese de Doutorado, Universidade Federal do Rio de Janeiro.

AMARAL, L. A., NADER, F. A., ROSSI JUNIOR, O. D., FERREIRA, L. A. \& BARROS, L. S. S. 2003. Água de consumo humano como fator de risco à saúde em propriedades rurais. Revista de Saúde Pública 37, 510-514.

APHA 1995. Standard Methods for the Examination of Waters and Wastewaters, Washington, DC, AMERICAN PUBLIC HEALTH ASSOCIATION.
BETTEGA, J. M. P. R., MACHADO, M. R., PRESIBELLA, M., BANISKI, G. \& BARBOSA, C. A. 2006. Métodos Analíticos no Controle Microbiológico da Água para Consumo Humano. Ciência e Agrotecnologia, 30, 950-954.

BRASIL 2000. Resolução CONAMA 274, de 29/11/2000. Revisa os critérios de Balneabilidade em Águas Brasileiras. In: CONAMA, C. N. D. M. A.-. (ed.) 274/2000. Brasília, DF: Diário Oficial da República, Ministério do Meio Ambiente.

BRASIL 2005. Resolução no 357 de 17 de março de 2005. Dispóe sobre a classificação dos corpos de água e diretrizes ambientais para o enquadramento, bem como estabelece as condiçóes e padróes de lançamento de efluentes, e dá outras providências. Diário Oficial [da] República Federativa do Brasil, 18 de maio de 2005.

COSTA., H. 1999. Subsídios para Gestão dos Recursos Hídricos das Bacias Hidrográficas dos rios Macacu, São João, Macaé e Macabu. Projeto Planágua/GTZ. Rio de Janeiro: Secretaria Estadual de Meio Ambiente e Desenvolvimento Susutentável.

DANTAS, J. R. C., ALMEIDA, J. R. \& LINS, G. A. 2008. Impactos ambientais na bacia hidrográfica de Guapi/Macacu e suas conseqüências para o abastecimento de água nos municípios do leste da Baía de Guanabara.Rio de Janeiro. Instrução Técnica. Rio de Janeiro: CETEM/MCT.

ECOLOGUS \& AGRAR 2003. Plano Diretor de Recursos Hìdricos da Região Hidrográfica da Baía de Guanabara Rio de Janeiro: FEEMA.

FORSYTHE, S. J. 2002. Microbiologia da segurança alimentar, Porto Alegre, RS, Artmed.

GRANT, W. D. \& LONG, P. E. 1989. Microbiología Ambiental, Zaragoza (España), Editora Acríbia, S.A.

HOADLEY, A. W., DUTKA, B. J., AMERICAN SOCIETY FOR, T. \& MATERIALS. COMMITTEE, D. O. W. 1977. Bacterial Indicators, Health Hazards Associated with Water: A Symposium ... Chicago, Ill., 28-29 June 1976, American Society for Testing and Materials. 
INSTITUTO BRASILEIRO DE GEOGRAFIA E ESTATÍSTICA 2009. Anuário Estatístico do Brasil. Rio de Janeiro, RJ: FUNDAÇÃO INSTITUTO BRASILEIRO DE GEOGRAFIA E ESTATÍSTICA

KAY, D. \& MCDONALD, A. 1980. Reduction of coliform bacteria in two upland reservoirs: the significance of distance, dacay relationships. Water Research, 14, 305-318.

KÖPPEN, W. 1948. Climatologia: con un estudio de los clima de la tierra. , Ciudad de Mexico, Fondo de Cultura Economia.

LOUREIRO, A., V., HENRIQUES, R. A. T., TRINDADE, R. M. \& GOUVÊIA, M. I. 2007. Relação da Qualidade da Água Servida com a Presença de Endoparasitoses em Escolares do Ensino Fundamental. Revista Cientifica da FAMINAS 3, 78-85.

MACHADO, C. J. S. \& KLEIN, H. E. 2003. Água, doença, saúde e arcabouço institucional-legal: por uma gestão integrada das águas do Estado do Rio de Janeiro. Revista Rio de Janeiro, 11, 13-38.

MÜllER, D., GREUNE, L., HEUSIPP, G., KARCH, H., FRUTH, A., TSCHÄPE, H. \& SCHMIDT, M. A. 2007. Identification of unconventional interstinal pathogenic Escherichia coli isolates expreshing intermediate virulence factor profiles by using a novel single step multiplex PCR. Applied and Environmental Microbiology, 73, 3380-3390.

OBI, C. L., POTGIETER, N., BESSONG, P. O. \& MATSAUNG , G. 2003. Scope of potential bacterial agents of diarrhoea and microbial assessment of quality of river water sources in rural Venda communities in South Africa. Water Science and Technology, 43, 59-64.
PAYMENT, P., WAITE, M. \& DUFOUR, A. 1997. Introducing Parameters for the Assessment of Drinking Water Quality. Guidelines WHO. Geneva: WHO.

ROMPRÉ, A., SERVAIS, P., BAUDART, J., DEROUBIN, M. R. \& LAURENT, P. 2002. Detection and enumeration of coliforms in drinking water: current methods and emerging. Journal of Microbiological Methods, 49, 31-54.

SILVA, J. M. \& FERREIRA, M. Q. M. Qualidade de efluentes. Simpósio sobre o Meio Ambiente e Desenvolvimento Sustentável do semi-árido, 2, 1997 Mossoró. UERN, 45-49.

SOARES, J. B. \& MAIA, A. C. F. 1999. Água Microbiologia e Tratamento, Fortaleza, CE, UFC Ediçôes.

WASSERMAN, J. C., BARCELLOS, R. G. S., FERNANDEZ, A. P. P., FILGUEIRAS, C. M., SCARTON, J. G. E., GIACOMINI, J., CÔRTES, M. B. V. \& AGUIAR, V. M. 2010. Qualidade de Água. In: DA HORA, A. F. F., HWA, C. S. \& DA HORA, M. A. G. M. (eds.) Planejamento Estratégico da Regiāo Hidrográfica dos Rios Guapi-Macacu e Caceribu-Macacu. Niterói: UFF/ FEC - Petrobras Ambiental. 